\title{
Estrogen Regulation of GABA Receptor Subunit mRNA Expression in Preoptic Area and Bed Nucleus of the Stria Terminalis of Female Rat Brain
}

\author{
Allan E. Herbison and Valérie S. Fénelon \\ Laboratory of Neuroendocrinology, The Brabraham Institute, Babraham, Cambridge CB2 4AT UK
}

This study has examined whether circulating estrogens are involved in regulating $\gamma$-aminobutyric acid (GABA) $A$ receptor mRNA expression in regions of the female rat brain known to contain estrogen receptors (ERs). In situ hybridization experiments using ${ }^{35} \mathrm{~S}$-labeled oligonucleotides specific for $\alpha_{2}$, $\beta_{3}$, and $\gamma_{1}$ subunit mRNAs of the GABA, receptor demonstrated that all three mRNAs were abundant in only the medial preoptic nucleus (MPN), where they were expressed by the vast majority of cells, and specific regions of the bed nucleus of the stria terminalis including the principle encapsulated nucleus (PrN-BNST) and bed nucleus of the anterior commissure (BNAC). Estrogen treatment of ovariectomized rats for $7 \mathrm{~d}$ resulted in significant $30-60 \%$ increases in $\alpha_{2}$ and $\gamma_{1}$, but not $\beta_{3}$, subunit mRNA expression in the MPN and PrN-BNST. Estrogen treatment for $24 \mathrm{hr}$ resulted in levels of mRNA expression intermediate between those of controls and animals treated with estrogen for $7 \mathrm{~d}$. No changes in subunit mRNA expression were detected for any subunit in the BNAC or cingulate cortex. Double-labeling immunocytochemistry experiments using antibodies directed against the $\alpha_{2}$ subunit of the GABA receptor and the ER, revealed that $67 \pm 3 \%$ of $\alpha_{2}$ subunit-immunoreactive cells in the MPN also contained ER immunoreactivity. Cells expressing $\alpha_{2}$ subunits in the PrN-BNST were also found to possess ERs while those in the BNAC and cingulate cortex did not. These findings suggest the possibility that ER-containing cells in the MPN and PrN-BNST express an $\alpha_{2} \beta_{3} \gamma_{1}$ isoform of the GABA receptor that has its $\alpha_{2}$ and $\gamma_{1}$ subunits regulated by circulating estrogen concentrations. Together, our observations indicate that estrogen may regulate GABA $_{\mathrm{A}}$ receptor $\mathrm{mRNA}$ expression at a transcriptional level and that this is only likely to occur within regions of the rat brain possessing ERs.

[Key words: bed nucleus of the stria terminalis, estrogen, estrogen receptors, GABA, GABA $A_{A}$ receptor subunits, in situ hybridization, immunocytochemistry, preoptic area]

GABA acts on chloride ion-gated $\mathrm{GABA}_{\mathrm{A}}$ receptors to inhibit the electrical activity of neurons throughout the adult mammalian brain. Molecular cloning has identified at least five distinct

\footnotetext{
Received May 10, 1994; revised Sept. 21, 1994; accepted Sept. 26, 1994.

We are grateful to Dr. W. Sieghart for the generous gift of the $\alpha_{2}$ subunit antibody and Abbott Laboratories for the use of the $\mathrm{H} 222$ antibody. Miss T. Hunt is thanked for secretarial assistance. V.F. is a Wellcome Trust European Travelling Fellow and A.H. a Lister Institute-Jenner Fellow.

Correspondence should be addressed to Dr. Allan Edward Herbison at the above address.

Copyright $\odot 1995$ Society for Neuroscience $0270-6474 / 95 / 152328-10 \$ 05.00 / 0$
}

classes of subunits, each with multiple subtypes $\left(\alpha_{1-6}, \beta_{1-4}, \gamma_{1-3}\right.$, $\delta$, and $\left.p_{1-2}\right)$, which are believed to be arranged in a heteropentameric fashion to produce a variety of pharmacologically distinct isoforms of the GABA A $_{\mathrm{A}}$ receptor (Olsen and Tobin, 1990; Luddens and Wisden, 1991; Nayeem et al., 1994). Although the precise subunit composition of a single $\mathrm{GABA}_{\mathrm{A}}$ receptor has yet to be determined in vivo, investigators have begun to dissect the functions of different subunits within the GABA receptor; the presence of specific $\alpha$ and $\beta$ subunits in recombinant heterooligomers have different effects on channel activity and ligand binding to the receptor and, in association with $\gamma$ subunits, determine its pharmacological profile (Pritchett et al., 1989; Sigel et al., 1990; Ymer et al., 1990; McKernan et al., 1991; Amin and Weiss, 1993; Bureau and Olsen, 1993; Wafford et al., 1993).

Substantial evidence accumulated over the last decade indicates that steroid hormones are important regulators of $\mathrm{GABA}_{\mathrm{A}}$ receptor function. In particular, interest has focused on the direct actions of progesterone metabolites on $\mathrm{GABA}_{\mathrm{A}}$ receptors and their likcly physiological role in modulating GABA actions at this receptor (Majewska, 1992; Paul and Purdy, 1992). In addition, however, estrogen has been implicated in the regulation of ligand binding to the $\mathrm{GABA}_{\mathrm{A}}$ receptor (Maggi and Perez, 1986; Lasaga et al., 1988; O'Connor et al., 1988; Schumacher et al., 1989a,b; Canonaco et al., 1993), although there is no evidence to suggest this steroid is a direct allosteric modulator of $\mathrm{GABA}_{\mathrm{A}}$ receptor. Further, as estrogen's influence on $\mathrm{GABA}_{\mathrm{A}}$ receptor ligand binding is restricted primarily to regions of the brain possessing estrogen receptors (ERs; O'Connor et al., 1988; Schumacher et al., 1989b; Canonaco et al., 1993), it is plausible that estrogen alters gene transcription to influence the $\mathrm{GABA}_{\mathrm{A}}$ receptor. To this end it is noteworthy that the preoptic area (POA) and bed nucleus of the stria terminalis (BNST) of the rat possess large populations of cells containing ERs (Cintra et al., 1986; Simerly et al., 1990) and are regions of the brain where estrogen alters the binding of ${ }^{35} S$-butylbicyclophosphorothiorate (TBPS) but not ${ }^{3} \mathrm{H}$-muscimol (O'Connor et al., 1988; Canonaco et al., 1993). Although the POA has been reported to express mRNAs for the $\alpha_{1,2,3,5}, \beta_{1-3}$, and $\gamma_{1,2}$ subunits of the GABA receptor (Araki and Tohyama, 1992; Wisden et al., 1992; Petersen et al., 1993a), the autoradiograms of Wisden and colleagues (1992) show that the $\alpha_{2}, \beta_{3}$, and $\gamma_{1}$ subunit mRNAs of the GA$\mathrm{BA}_{\mathrm{A}}$ receptor are the only ones to be expressed in any strength within the medial preoptic nucleus (MPN) of the POA and the principle encapsulated nucleus of the BNST (PrN-BNST; Wisden et al., 1992); the two nuclei in which ER-containing cells are concentrated (Cintra et al., 1986; Simerly et al., 1990; Herbison and Theodosis, 1992). As such, these three $\mathrm{GABA}_{\mathrm{A}}$ re- 
ceptor subunits are good candidates for transcriptional regulation by the ER in the POA and BNST. Using in situ hybridization techniques, we have addressed this issue by examining the distribution of cells possessing mRNAs for $\alpha_{2}, \beta_{3}$, and $\gamma_{1}$ subunits in the POA and BNST and determining the effects of estrogen on $\alpha_{2}, \beta_{3}$, and $\gamma_{1}$ subunit mRNA expression in these areas. In addition, using antibodies that detect the ER and $\mathrm{GABA}_{\mathrm{A}}$ receptor $\alpha_{2}$ subunit proteins, double-labeling immunocytochemistry techniques have been employed to assess whether $\alpha_{2}$ subunits are, indeed, expressed by ER-immunoreactive cells in the POA and BNST.

\section{Materials and Methods}

Adult female Wistar rats from the Babraham colony were maintained in a light and temperature-controlled environment (lights on 0500-1900 $\mathrm{hr}, 22^{\circ} \mathrm{C}$ ) with food and water freely available. All ovariectomies were undertaken on animals anesthetized with Avertin (2\% tribromoethanol, $1.0 \mathrm{ml} / 100 \mathrm{gm}$ body weight, i.p.) and experiments were conducted in accordance with Home Office requirements for Animal Scientific Procedures (Project 80/00704).

In situ hybridization experiments. Three groups of rats were ovariectomized and used 4 weeks later for in situ experiments. The first group of animals (OVX; $n=5$ ) received subcutaneous implants of empty SILASTIC capsules (Dow Corning; length $14 \mathrm{~mm}$, i.d. 0.062 in, o.d. 0.125 in; Dow Corning, USA) 1 week before being killed. The second group (OVX-E7d; $n=5$ ) received SILASTIC implants filled with a 50 $\mu \mathrm{g}$ 17- $\beta$ estradiol $/ \mathrm{ml}$ ethyl oleate solution at the same time, while a third group (OVX-E1d; $n=5$ ) received the same estradiol-filled capsule but $24 \mathrm{hr}$ prior to decapitation. Estradiol capsules prepared and administered in this way return plasma estradiol concentrations to physiological levels observed at metestrous within $24 \mathrm{hr}$ in female rats (Leipheimer et al., 1984). Between 1000 and $1200 \mathrm{hr}$, all rats were stunned by a blow to the back of the neck and decapitated, their brains removed, and frozen on dry ice. Fresh frozen sections (15 $\mu \mathrm{m}$ thick) were cut in the coronal plane through the POA and anterior hypothalamic area, thaw mounted onto gelatinized slides, and stored at $-70^{\circ} \mathrm{C}$.

Antisense oligonucleotides (42-45-mer) complementary to the coding regions for amino acids 340-354, 382-396, and 341-354 of the rat GABA $A_{A}$ receptor $\alpha_{2}, \beta_{3}$, and $\gamma_{1}$ subunits, respectively, were synthesized. These exact probe sequences have been used by others to assess $\alpha_{2}, \beta_{3}$, and $\gamma_{1}$ subunit mRNA expression in the rat brain and the $\alpha_{2}$ and $\beta_{3}$ specificity verified further using Northern blot analysis (Khrestchatisky et al., 1991; Ymer et al., 1989, 1990; Wisden et al., 1992). Each probe (100 ng) was 3' end-labeled to a specific activity of approximately $10^{9}$ $\mathrm{cpm} / \mu \mathrm{g}$ by incubation with ${ }^{35} \mathrm{~S}-\mathrm{dATP}(1000-1500 \mathrm{Ci} / \mathrm{mmol}$; New England Nuclear NEG $034 \mathrm{H}$ ) and $50 \mathrm{U}$ terminal deoxynucleotidyl transferase (Pharmacia, UK) in tailing buffer at $37^{\circ} \mathrm{C}$ for $30 \mathrm{~min}$. Radiolabeled probes were purified by gel filtration on a Sephadex G-50 column. Brain sections from all three experimental groups were processed simultaneously for each oligonucleotide. Frozen sections were warmed to room temperature with a hair dryer and fixed in $4 \%$ paraformaldehyde/ $0.1 \mathrm{M}$ phosphate buffer for $20 \mathrm{~min}$. Sections were then rinsed in $0.1 \mathrm{M}$ phosphate-buffered saline before being dehydrated through a series of graded ethanols, rehydrated in $95 \%$ ethanol, and finally left to air dry at room temperature. For hybridization, ${ }^{35} \mathrm{~S}$-labeled probes were diluted in hybridization buffer ( $50 \%$ deionized formamide, $4 \times$ SSC, $10 \%$ dextran sulphate, $1 \times$ Denhardt's solution, $250 \mu \mathrm{g} / \mathrm{ml}$ sheared salmon testis DNA, $3 \% \beta$-mercaptoethanol) to a final concentration of approximately $2 \times 10^{3} \mathrm{cpm} / \mu \mathrm{l}$, and $250 \mu \mathrm{l}$ of diluted probe was applied to each slide containing four coronal brain sections. Following an overnight hybridization at $37^{\circ} \mathrm{C}$, sections were rinsed in $1 \times \mathrm{SSC}$ at room temperature $(5 \mathrm{~min})$, three times at $55^{\circ} \mathrm{C}(30 \mathrm{~min}$ each), and then for $1 \mathrm{hr}$ at room temperature. After a brief rinse in $\mathrm{dH}_{2} \mathrm{O}$ followed by $70 \%$ ethanol $/ 300$ $\mathrm{mm}$ ammonium acetate $(30 \mathrm{sec})$ and then absolute alcohol $(30 \mathrm{sec})$, sections were left to air dry before being apposed to Hyperfilm $\beta$-Max (Amersham) for 3 weeks. Slides were then dipped in Ilford K-5 nuclear track emulsion and exposed for 8-10 weeks in dark-tight boxes. After developing with Ilford Phenisol $\left(1: 5,5 \mathrm{~min}\right.$ at $\left.20^{\circ} \mathrm{C}\right)$, slides were counterstained lightly with methylene blue and coverslipped. Signal specificity was assessed by use of competition experiments in which radiolabeled probes were hybridized to sections in the presence of a 25 -fold excess of unlabeled probe.

Immunocytochemical studies. The monoclonal rat $\mathrm{H} 222$ antibody is directed against the hormone binding domain of the ER and, in rats, stained nuclei are only clearly detected in ovariectomized animals (Cintra et al., 1986; Herbison and Theodosis, 1992). Five rats were ovariectomized and perfused $10 \mathrm{~d}$ latter. All animals were deeply anesthetized with Avertin and perfused intracardially with heparinized saline ( $25 \mathrm{IU}$ heparin/ml) followed by $4 \%$ paraformaldehyde in $0.1 \mathrm{M}$ sodium phosphate buffer $(\mathrm{pH}=7.6)$ for $10-15 \mathrm{~min}$. Brains were then removed and a block containing the POA and BNST postfixed in the same $4 \%$ paraformaldehyde solution for 1-2 hr before being transferred into a $0.05 \mathrm{M}$ Tris-buffered saline (TBS) containing $25 \%$ sucrose at $4^{\circ} \mathrm{C}$. Coronal sections $(25 \mu \mathrm{m})$ were taken through the POA and anterior hypothalamic area, washed several times in TBS, and then placed in $1 \%$ normal sheep serum/TBS for $1 \mathrm{hr}$ at room temperature. For $\mathrm{GABA}_{\mathrm{A}}$ receptor $\alpha_{2}$ subunit immunostaining, sections were incubated with an affinity purified polyclonal rabbit antisera $(3 \mu \mathrm{g} / \mathrm{ml})$ recognizing amino acids $416-424$ of the $\alpha_{2}$ subunit overnight at $4^{\circ} \mathrm{C}$ (Gift of W. Sieghart, Vienna). The next day sections were washed in TBS and incubated for $90 \mathrm{~min}$ in biotinylated goat anti-rabbit immunoglobulins $(1: 200$, Vector UK) followed by streptavidin-biotin-peroxidase complex (1:200, Amersham UK) for another $90 \mathrm{~min}$. Immunoreactivity was visualized using a nickel-enhanced 3,3'-diaminobenzidine tetrahydrochloride (DAB) procedure (Shu et al., 1988). Immunostaining for the ER, and double labeling was carried out on sections from ovariectomized rats as described previously (Herbison and Theodosis, 1992). In brief, the monoclonal rat $\mathrm{H} 222$ antibody directed against the human ER (Gift of Abbott Labs., Chicago, IL) was incubated with sections for $40 \mathrm{hr}$ at a $1.3 \mu \mathrm{g} /$ $\mathrm{ml}$ concentration. Immunoreactivity was visualized using biotinylated anti-rat immunoglobulins (1:200, Amersham, UK) followed by the nickel-DAB procedure outlined above. Sequential double staining of sections was carried out by selecting ER-stained sections, washing them in TBS followed by a $40 \%$ methanol, $1 \% \mathrm{H}_{2} \mathrm{O}_{2}$-TBS solution for 15 min, and incubation in the $\alpha_{2}$ subunit antiserum as described. Immunoreactivity was visualized using peroxidase-labeled anti-rabbit immunoglobulins ( $3 \mathrm{hr}, 1: 200$; Vector, UK) and DAB without nickel as the chromogen. All immunolabels were diluted in TBS containing $0.25 \%$ BSA with $0.3 \%$ Triton- $X$. The production and specificity of each antiserum has been reported previously (Greene et al., 1980; Cintra et al.,1986; Buchstaller et al., 1991; Zezula et al., 1991; Zimprich et al., 1991). For the $\alpha_{2}$ subunit antibody, a solid phase absorption control was performed by placing POA sections with $\alpha_{2}$ antiserum previously incubated with $140 \mu \mathrm{g}$ of the $\alpha_{2}$ nonapeptide (gift of W. Sieghart) absorbed on $\mathrm{CNBr}$-activated Sepharose-4B beads $(0.25 \mathrm{gm}$ overnight at $4^{\circ} \mathrm{C}$, Pharmacia, UK). Other controls consisted of the omission of primary antibodies and incubation of sections in inappropriate secondary antibodies. In all control experiments, no specific staining was evident.

Data analysis. For in situ hybridization experiments, relative numbers of silver grains overlying individual cells in the medial division of the medial preoptic nucleus (MPN), PrN-BNST, and layers 2 and 3 of the cingulate cortex were determined using a Joyce-Loebl Magiscan analyzer coupled to a Leica Orthoplan microscope. In each of these regions, 20-25 labeled cells were analyzed from both sides of the brain of each animal. In relatively cell-dense regions such as the MPN and PrNBNST, care was taken to analyze only those cells for whom the silver grains were clearly attributable to a single cell. Initially, the numbers of silver grains overlying cells in the excess unlabeled probe control sections were determined and in experimental sections, only those cells expressing numbers of silver grains greater than 5 times that of controls were used for analysis. For each rat and each region an average silver grain count/cell was determined and these values combined to give experimental group means. Silver grain analysis was also undertaken in the bed nucleus of the anterior commissure (BNAC) within the BNST, although the very high density of cells in this region precluded any individual cell analysis. Instead, silver grain density was determined using the Joyce-Loebl Magiscan by counting the numbers of silver grains overlying defined areas of the BNAC in two to three sections from each rat and represented as silver grains $/ \mu^{2}$. In all cases, statistical analysis was determined using ANOVA followed by the nonparametric Mann-Whitney $U$ test.

A semiquantitative analysis of double-labeled immunoreactive cells was carried out by counting the numbers of ER-, $\alpha_{2}$ subunit- and double-labeled cells in the MPN of ovariectomized rats using a Leica DM RB microscope at $40 \times$ objective magnification. For each rat, two to four sections through the MPN at the level depicted in Figure 5, were analyzed by counting all immunoreactive cells within a $1 \mathrm{~mm}$ by $1 \mathrm{~mm}$ reference frame placed over the MPN. 

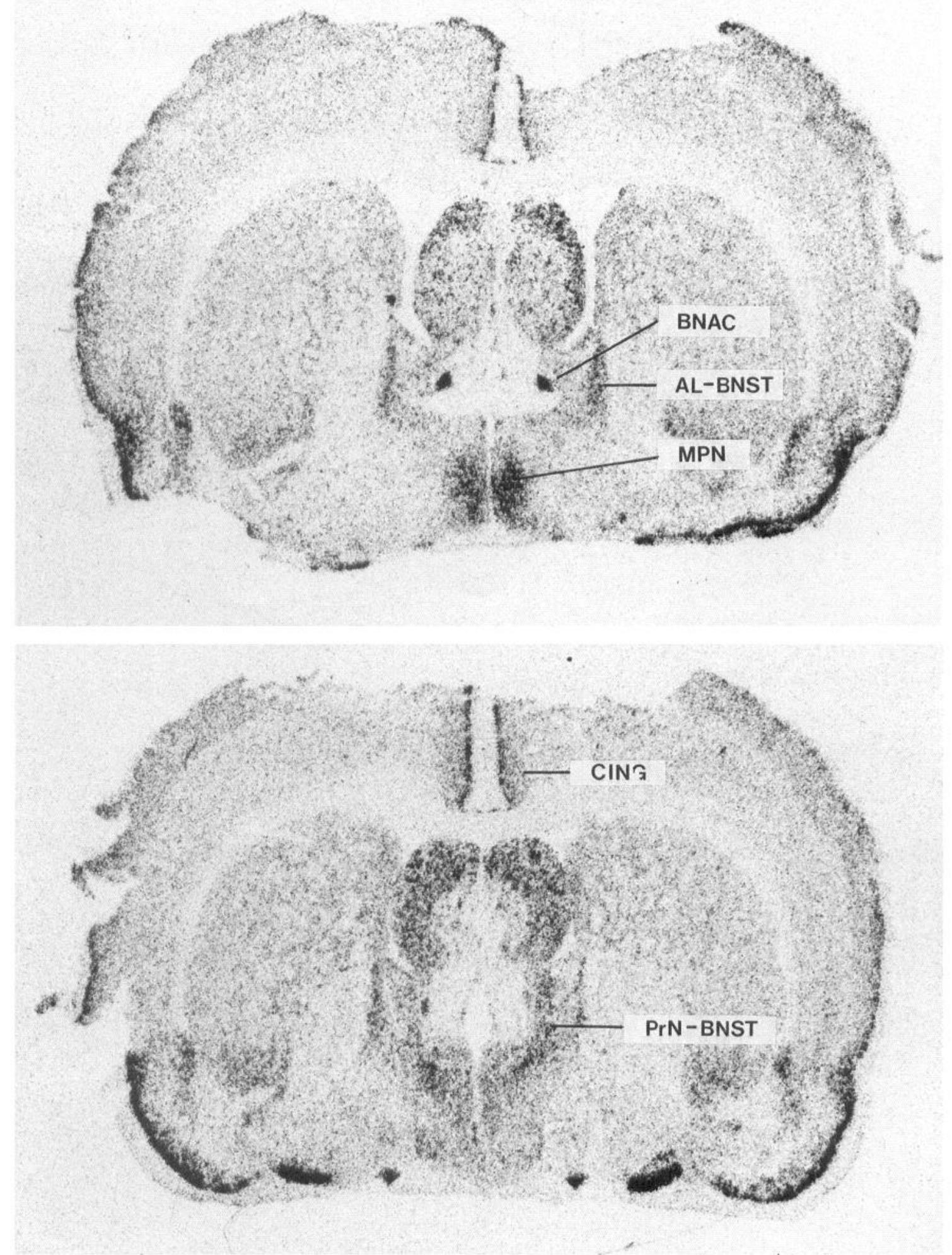

Figure 1. Distribution of $\mathrm{GABA}_{\mathrm{A}}$ receptor $\alpha_{2}$ subunit mRNA transcripts in coronal sections of the female rat brain taken through the medial preoptic nucleus (top) and anterior hypothalamic area (bottom). $A L-B N S T$, anterolateral division of the bed nucleus of the stria terminalis; $B N A C$, bed nucleus of the anterior commissure; $C I N G$, cingulate cortex; $M P N$, medial preoptic nucleus; $\operatorname{PrN}$-BNST, principle encapsulated nucleus of the bed nucleus of the stria terminalis. 

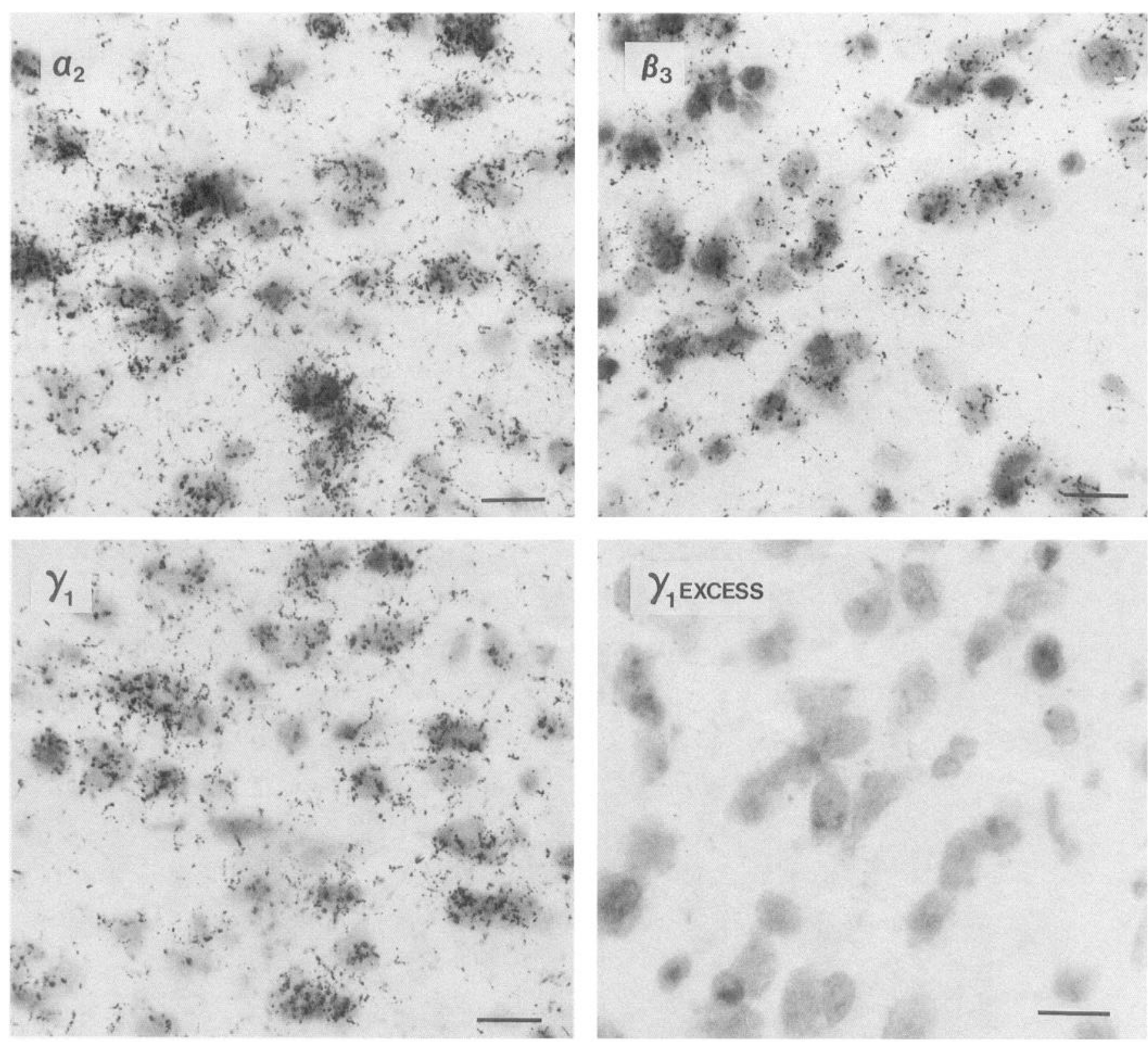

Figure 2. High-power views of cells in the medial preoptic nucleus expressing $\alpha_{2}, \beta_{3}$, and $\gamma 1$ subunit mRNAs. $\gamma_{1}$ EXCESS shows hybridization signal following excess unlabeled probe control experiments (see Materials and Methods). Note that most cells express the $\beta_{3}$ subunit while almost all cells contain $\alpha_{2}$ and $\gamma_{1}$ subunit mRNA transcripts. Scale bars, $15 \mu \mathrm{m}$.

\section{Results}

In situ hybridization experiments

The distribution of hybridized probe was first assessed by film autoradiography and then verified by examining silver grain distribution and the intensity of labeling recorded (heavy +++ , moderate ++ , light + ). For the $\alpha_{2}$ oligonucleotide (Figs. 1, 2), labeled cells were identified within the MPN $(+++)$, median preoptic nucleus $(+++)$, anteroventral periventricular nucleus $(++)$, supraoptic nucleus $(+++)$, horizontal nucleus of the diagonal band of Broca $(++)$, and suprachiasmatic nucleus $(+)$ of the anterior hypothalamic/POA region; the PrN-BNST $(+++)$, BNAC $(+++)$, magnocellular and posterodorsal nuclei $(+++)$, and anterolateral division $(++)$ of the BNST (classification of Ju and Swanson; 1989); lateral septum $(+++)$, piriform cortex $(+++)$, cingulate cortex layers 2 and $3(+++)$, cerebral cortex (elsewhere) layers 2 and $3(++)$, and caudateputamen ( + ). The distribution of the $\beta_{3}$ signal was remarkably similar to that observed for $\alpha_{2}$ being found in all of the regions described above, although overall numbers of $\beta_{3}$-derived silver grains were lower than for $\alpha_{2}$ (Figs. 2, 3). Moderate or heavy hybridization signal for $\gamma_{1}$ (Fig. 2) was restricted to the hypothalamic/POA/BNST regions; MPN $(+++)$, anteroventral periventricular nucleus $(++)$, PrN-BNST $(+++)$, BNAC $(++)$, magnocellular and posterodorsal nuclei $(+++)$, and anterolateral division of the BNST $(++)$. At the exposure times used in these experiments $\gamma_{1}$-expressing cells were not detected in the cerebral cortex including piriform and cingulate regions. Competition experiments with unlabeled oligonucleotides abolished specific labeling of cells with all three oligonucleotides (Fig. 2).

Quantitative silver grain analysis was carried out in the MPN, 

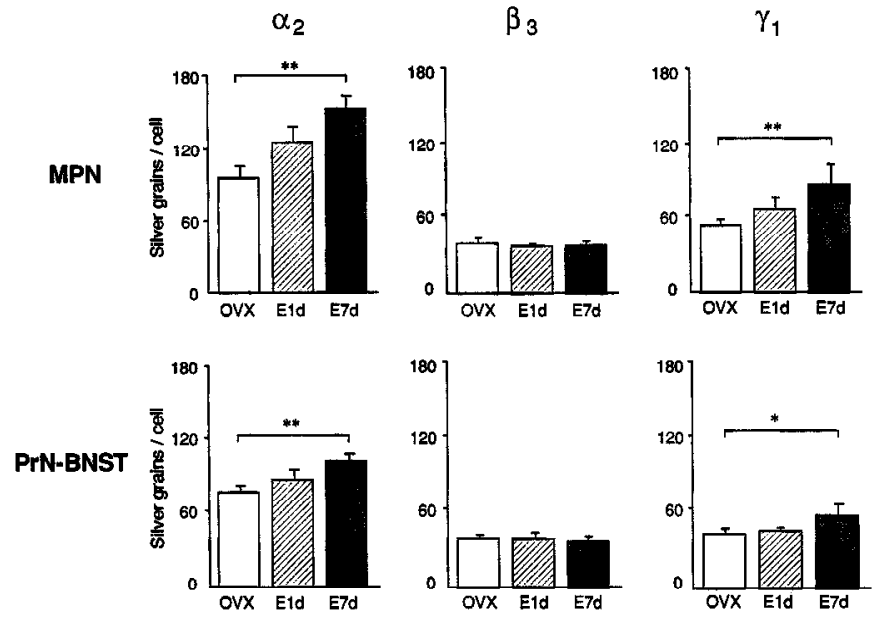

Figure 3. Quantitative analysis of silver grain numbers per cells following $\alpha_{2}, \beta_{3}$, and $\gamma_{1}$ subunit mRNA hybridizations in the medial preoptic nucleus $(M P N)$ and principle encapsulated nucleus of the bed nucleus of the stria terminalis ( $\operatorname{PrN}-B N S T)$ of ovariectomized rats treated with oil $(O V X)$ or estradiol for $1(E d l)$ or $7(E 7 d) \mathrm{d}$. Bars give means + SEM. ${ }^{*} p<0.05,{ }^{* *} p<0.01$.

PrN-BNST, and BNAC for all three oligonucleotides and in the cingulate cortex (layers 2 and 3 ) for $\alpha_{2}$ and $\beta_{3}$. Estrogen treatment for $7 \mathrm{~d}$ (OVX-E7d) was found to significantly increase the numbers of silver grains/cell in the MPN and PrN-BNST for the $\alpha_{2}(p<0.01-0.05)$ and $\gamma_{1}(p<0.01-0.05)$ but not the $\beta_{3}$ subunit (Fig. 3). In each of these regions, OVX-E1d rats showed an intermediate number of silver grains/cell compared with the other two groups, but were not significantly different from either $\left(p>0.05\right.$ ). No significant differences were detected for $\alpha_{2}, \beta_{3}$, or $\gamma_{1}$ subunits in the BNAC or $\alpha_{2}$ and $\beta_{3}$ subunits in the cingulate cortex (Table 1). The numbers of cells expressing $\alpha_{2}, \beta_{3}$, or $\gamma_{1}$ mRNA were not quantified, but it appeared that almost all cells in the MPN and PrN-BNST expressed $\alpha_{2}$ and $\gamma_{1}$ subunits while around two-thirds of these cells expressed the $\beta_{3}$ subunit (Fig. 2). The three subunits were expressed by all cells in the BNAC.

\section{Immunocytochemistry experiments}

Immunoreactivity for the $\mathrm{GABA}_{\mathrm{A}}$ receptor $\alpha_{2}$ subunit was detected throughout the coronal brain sections as either a diffuse neuropil or distinct cell body staining. As reported previously with this antibody (Zimprich et al., 1991), immunoreactivity localized to cell bodics existcd as a combination of cytoplasmic and membrane staining. Within the rostral hypothalamic area, strongly immunoreactive cells were detected in the MPN (Figs. $4 A, B ; 5 A$ ), anteroventral periventricular and supraoptic nuclei, while less intense immunoreactivity was observed in the suprachiasmatic nuclcus and latcral hypothalamus. In the septum and BNST, strong immunoreactivity was restricted to cell body staining in the lateral septum and BNAC (Fig. 4C), with the PrNBNST (Fig. 5D), magnocellular and posterodorsal nuclei, and anterolateral division of the BNST exhibiting moderate to light cell body staining. Elsewhere in the coronal sections, strong to moderate immunoreactivity was observed within cells in the piriform and cingulate (Fig. $4 D$ ) cortices and the horizontal nucleus of the diagonal band of Broca.

Estrogen receptor staining was identical to that reported by others (Cintra et al., 1986) and ourselves (Herbison and Theodosis, 1992) in these areas and consisted of nuclear labeling of large numbers of cells in the MPN (Fig. 5B), PrN-BNST (Fig. $5 E$ ) and posterodorsal nucleus of the BNST. ER-immunoreactive cells were also noted outside the MPN in the periventricular region, lateral hypothalamus, and throughout the BNST including the magnocellular and anterolateral nuclei but not the BNAC. As first noted by Cintra and colleagues (1986), nonspecific staining of ependymal cells was also evident.

Double labeling experiments revealed large numbers of cells exhibiting black ER nuclear staining combined with brown $\alpha_{2}$ cytoplasmic/membrane staining in the MPN (Fig. 5C). Smaller numbers of lighter stained double-labeled cells were detected in the PrN-BNST (Fig. 5E, inset). Cell count estimates showed that $67 \pm 3 \%$ of the $\alpha_{2}$ subunit immunoreactive cells in the MPN possess ERs and that these double-labeled cells accounted for $17 \pm 2 \%$ of ER-containing cells in the MPN. As $\alpha_{2}$ subunit immunoreactivity was relatively faint in the BNST after the double-labeling procedure, a semiquantitative analysis of single- and double-labeled cells was not undertaken.

\section{Discussion}

The present results show that circulating estrogen concentrations influence mRNA levels of specific $\mathrm{GABA}_{\mathrm{A}}$ receptor subunits within ER-containing regions of the rat brain. Further, we show that the $\alpha_{2}$ subunit is expressed by cells possessing ERs in the MPN and PrN-BNST. Such findings indicate that estrogen may alter gene transcription to influence $\mathrm{GABA}_{\mathrm{A}}$ receptor functioning in specific regions of the rat brain. In particular, it is important to note that the MPN is established as an important brain structure in the gonadal steroid-dependent control of reproductive behavior and reproductive hormone secretion in female rats (Freeman, 1994; Pfaff et al., 1994). Although the BNST is sim-

Table 1. Silver grain analysis of $\alpha_{2}, \beta_{3}$, and $\gamma_{1}$ subunit mRNA expression in the layers 2 and 3 of the cingulate cortex and bed nucleus of the anterior commissure in ovariectomized (OVX) rats and following estrogen treatment for $1 \mathrm{~d}$ (OVX-E1d) or $7 \mathrm{~d}$ (OVX-E7d).

\begin{tabular}{lllll} 
Area & Treatment & $\alpha_{2}$ & $\beta_{3}$ & $\gamma_{1}$ \\
\hline Cingulate cortex & OVX & $88.3 \pm 6.9$ & $62.9 \pm 4.5$ & - \\
(silver grains/cell) & E1d & $82.8 \pm 5.0$ & $49.7 \pm 4.8$ & - \\
& E7d & $77.7 \pm 2.5$ & $60.0 \pm 7.9$ & - \\
Bed nucleus of the anterior & OVX & $0.89 \pm 0.17$ & $0.28 \pm 0.03$ & $0.23 \pm 0.01$ \\
commissure (silver grains/ & E1d & $0.74 \pm 0.12$ & $0.28 \pm 0.05$ & $0.24 \pm 0.02$ \\
$\mu \mathrm{m}^{2}$ & E7d & $1.15 \pm 0.28$ & $0.30 \pm 0.03$ & $0.26 \pm 0.03$ \\
\hline
\end{tabular}

For the cingulate cortex, numbers give mean \pm SEM for number of silver grains/cell while analysis in the bed nucleus of the anterior commisure gives silver grain densities for the whole nucleus. Note that $\gamma_{1}$ mRNA-expressing cells were not detected in the cingulate cortex. 

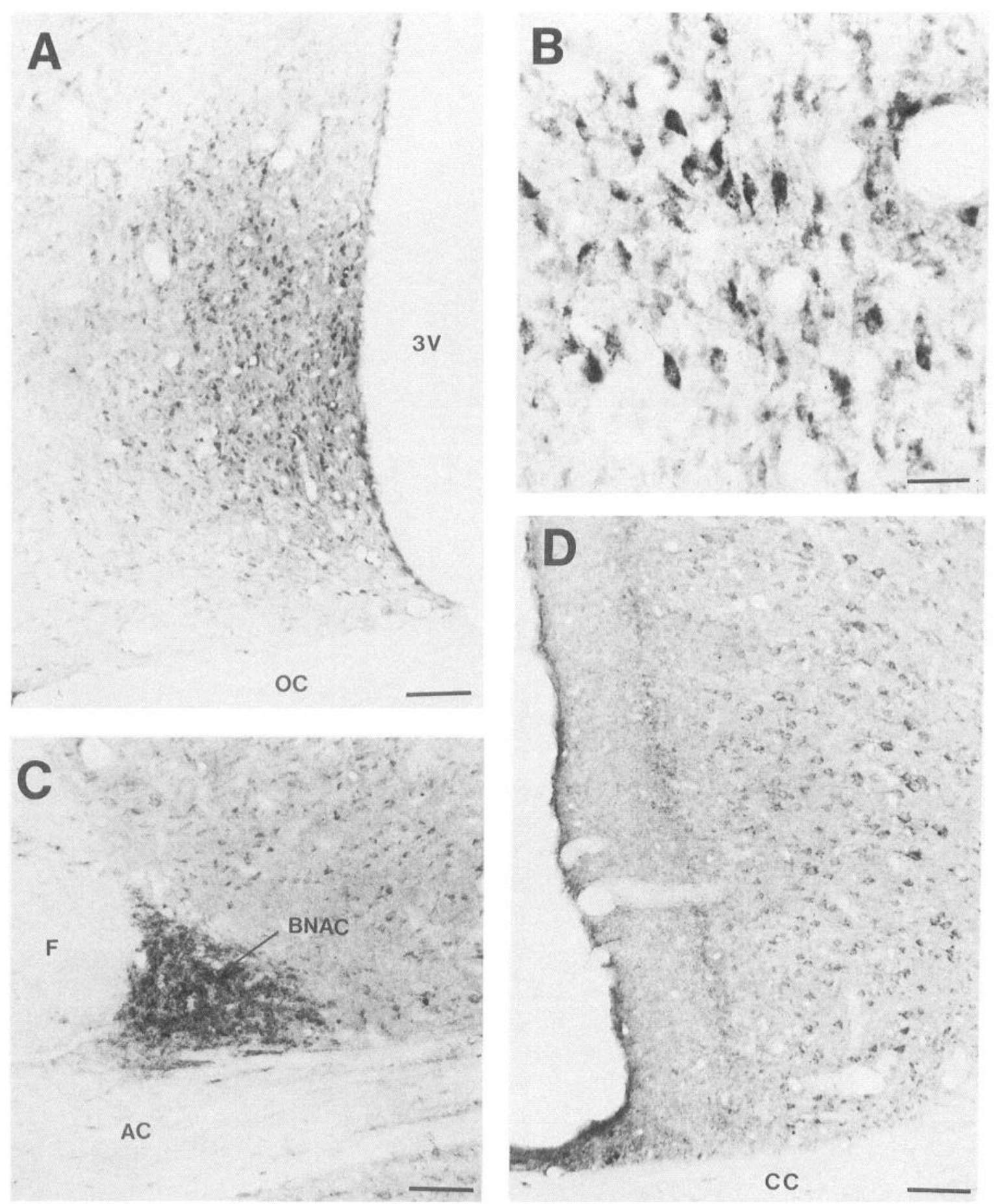

Figure 4. Immunocytochemical staining for the $\alpha_{2}$ subunit of the GABA receptor in the medial preoptic nucleus $(A$ and $B$ ), bed nucleus of the anterior commissure $(C)$, and cingulate cortex $(D)$. $A C$, anterior commissure; $B N A C$, bed nucleus of the anterior commissure; $C C$, corpus callosum; $F$, fornix; $O C$, optic chiasm; $3 V$, third ventricle. Scale bars: $A$ and $C, 80 \mu \mathrm{m} ; B, 20 \mu \mathrm{m} ; D, 50 \mu \mathrm{m}$.

ilarly implicated in the neural control of reproduction (Terasawa and Kawakami, 1974), the precise roles of its various subnuclei are not well established. Nevertheless, the selective predominance of ER-containing neurons in the PrN-BNST and the strong Fos expression in this region following mating in female rats (Tetel et al., 1993) suggest a role in the integration of steroidal and sensory stimuli with respect to reproductive behavior.

The distribution of hybridized cells and relative strength of expression for $\alpha_{2}, \beta_{3}$, and $\gamma_{1}$ mRNA transcripts in our experi- ments appear identical to that reported by Wisden and colleagues (1992) using the same ${ }^{35} \mathrm{~S}$-labeled oligonucleotide probe sequences and are in good agreement with other workers examining $\alpha_{2}$ (MacLennan et al., 1991), $\beta_{3}$ (Zhang et al., 1991), and $\gamma_{1}$ (Ymer et al., 1990) mRNA expression in the rat brain. With respect to the $\alpha_{2}$ subunit, it is reassuring to note that the distribution of $\alpha_{2}$ mRNA-positive cells is in good agreement with our $\alpha_{2}$ immunoreactivity observations. In particular, the strong expression of $\alpha_{2}$ mRNA in the MPN and 

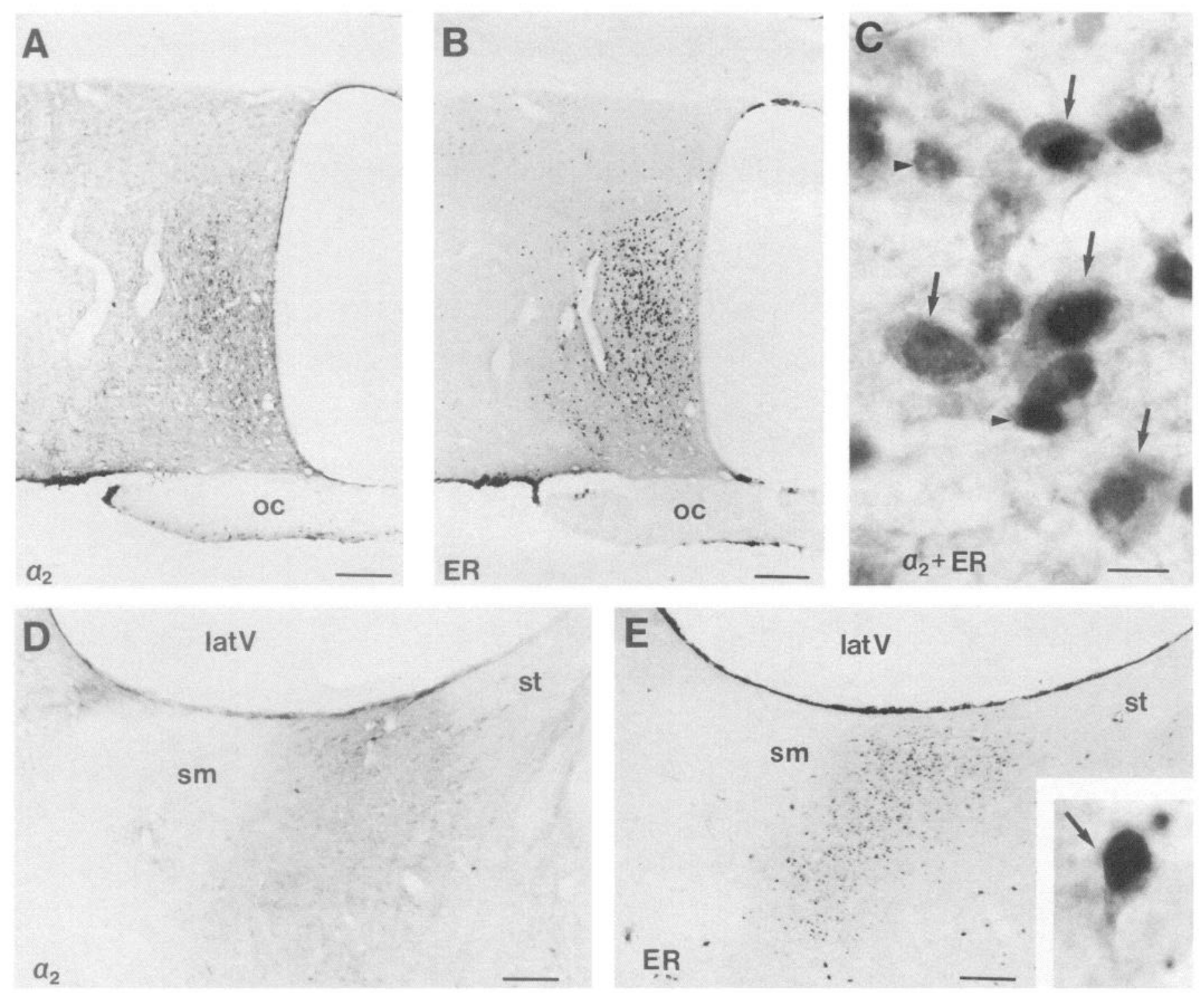

Figure 5. Single- and double-labeling immunocytochemistry stainings on consecutive sections for the $\alpha_{2}$ subunit of the GABA receptor ( $A$ and $D$ ), estrogen receptor $(E R ; B$ and $E$ ), and both receptors $(C$ and $E$, inset) at the level of the medial preoptic nucleus $(A-C)$ and principle encapsulated nucleus of the bed nucleus of the stria terminalis $\left(D\right.$ and $E$ ). Note the overlapping distribution of the $\alpha_{2}$ subunit- and estrogen receptor immunoreactivity in the medial preoptic nucleus $(A$ and $B)$. $C$ shows a high-power view of double-labeled cells (arrows) immunoreactive for the estrogen receptor (black nuclear stain) and $\alpha_{2}$ subunit (cytoplasmic/membrane immunoreactivity). Cells only immunoreactive for the estrogen receptor are indicated by arrowheads. In the principle encapsulated nuclei note the relatively faint $\alpha_{2}$ subunit staining $(D)$ that overlaps with that of the estrogen receptor distribution $(E)$ and that double-labeled cells were also detected (arrow, inset, $E$ ). $E R$, estrogen receptor; lat $V$, lateral ventricle; sm, stria medularis; st, stria terminalis; $o c$, optic chiasm. Scale bars: $A$ and $B, 200 \mu \mathrm{m} ; C, 10 \mu \mathrm{m} ; D$ and $E, 150 \mu \mathrm{m}$.

BNAC correlates well with the intense $\alpha_{2}$ immunoreactivity in these regions. While this correlation is good at a qualitative level, as it is elsewhere in the brain for $\alpha_{2}$ mRNA and this particular antibody (Zimprich et al., 1991; Wisden et al., 1992), the relationship, in general, between $\mathrm{GABA}_{\mathrm{A}}$ receptor protein levels and mRNA expression is not well defined. We find here that all of the regions expressing strong $\alpha_{2}$ subunit immunoreactivity such as the MPN, median preoptic nucleus, lateral septum, cingulate, and piriform cortices, also have the highest levels of $\alpha_{2}$ subunit mRNA expression. However, we note that silver grain numbers per cell in the PrN-BNST are not substantially different from those of MPN cells in the ovariectomized rat and yet $\alpha_{2}$ subunit immunocytochemistry is noticeably weaker in the former. Furthermore, our in situ data suggest that the great majority of MPN cells synthesize $\alpha_{2}$ subunit mRNAs and yet our immunocytochemical results show that it is only a subpopulation of MPN cells, possibly half, that possess detectable immunoreactivity. Such results may depend solely on the limitations of immunocytochemical analysis at the level of the light microscope. Nevertheless, the differences in $\alpha_{2}$ immunoreactivity between two regions expressing approximately equivalent amounts of mRNA raises the issues of posttranslational modification of $\mathrm{GABA}_{\mathrm{A}}$ receptor proteins and the possible dependence of $\alpha_{2}$ immunoreactivity on its subunit glycosylation and/or association with other subunits within the hetero-oligomer.

As noted previously by Wisden and colleagues (1992), there is substantial overlap in the distribution of $\alpha_{2}$ and $\beta_{3}$ subunit 
mRNAs throughout the brain. However, as mRNA for the $\gamma_{1}$ subunit is only readily detected in the POA, hypothalamus, and BNST, the combined expression of $\alpha_{2}, \beta_{3}$, and $\gamma_{1}$ mRNAs is restricted almost entirely to these hypothalamic/limbic regions of the brain (Ymer et al., 1990; Wisden et al., 1992). In this study, we observed that the great majority of cells in the MPN, PrN-BNST, and BNAC express $\alpha_{2}, \beta_{3}$, and $\gamma_{1}$ subunit mRNAs. This suggests that individual cells in these areas may synthesize all three subunits and that an $\alpha_{2} \beta_{3} \gamma_{1}$ isoform of the GA$B_{A}$ receptor may be used by these cells. Although we are unable to verify this hypothesis from the present studies, the apparent absence of abundant mRNA transcripts for other subunits of the GABA $A_{A}$ receptor within the MPN and PrN-BNST (Zhang et al., 1991; Wisden et al., 1992) strengthens this possibility. If this is the case, the $\alpha_{2} \beta_{3} \gamma_{1}$ isoform of the GABA receptor, which may also exist in the medial amygdala (see Wisden et al., 1992), would provide a selective pharmacological target for limbic and neuroendocrine networks in the brain. To our knowledge, the pharmacology of an expressed $\alpha_{2} \beta_{3} \gamma_{1}$ $\mathrm{GABA}_{\mathrm{A}}$ receptor isoform has not been examined, although extracellular recordings in vivo have shown inhibitory responses from almost all cells in the POA in response to GABA (Mayer, 1981).

Estrogen has been reported previously to alter ${ }^{35} \mathrm{~S}$-TBPS binding in the POA of the rat (Canonaco et al., 1993). We show here that estrogen increases mRNA expression of $\alpha_{2}$ and $\gamma_{1}$, but not $\beta_{3}$, subunits within this region. It is known that muscimol binds relatively weakly to $\mathrm{GABA}_{\mathrm{A}}$ receptors possessing $\alpha_{2}$ subunits (McKernan et al., 1991) and the observation here of abundant, estrogen-regulated $\alpha_{2}$ mRNA expression may underlie both the poor labeling of the POA and BNST with ${ }^{3} \mathrm{H}$ muscimol (Olsen et al., 1990) and the inability of a variety of estrogen treatments to alter muscimol labeling in these regions (O'Connor et al., 1988). In contrast, TBPS binding is strong in this area (Olsen et al., 1990) and reduced following the administration of estrogen to ovariectomized rats for $24 \mathrm{hr}$ (Canonaco et al., 1993). Although the precise manner of TBPS binding to the $\mathrm{GABA}_{\mathrm{A}}$ receptor is unknown, the inverse correlation between estrogen effects on $\alpha_{2}$ and $\gamma_{1}$ mRNA expression and TBPS binding suggests that this ligand may have relatively low affinity for one or both of these subunits.

In present study, significant differences in $\alpha_{2}$ and $\gamma_{1}$ subunit mRNA expression were detected after treating ovariectomized animals with estrogen for $7 \mathrm{~d}$; animals given estrogen for 24 hr always showed increased $\alpha_{2}$ and $\gamma_{1}$ expression in the MPN and PrN-BNST, although this was not significantly different to levels observed in control animals. The increase in plasma estradiol concentrations from low levels in ovariectomized rats to approximately $25 \mathrm{pg} / \mathrm{ml}$ in our estrogen-treated animals (Leipheimer et al., 1984) are well within the range of estradiol concentration fluctuations of $10-50 \mathrm{pg} / \mathrm{ml}$ seen during the estrous cycle in the rat (Freeman, 1994). The specificity of this selective increase in $\mathrm{GABA}_{\mathrm{A}}$ receptor subunit mRNA expression for brain regions possessing the ER is demonstrated by the lack of any change in the cingulate cortex and, in particular, cells of the BNAC that synthesize $\alpha_{2} \beta_{3} \gamma_{1}$ subunits, but unlike their near neighbors in the BNST, do not possess ERs.

We are unable to determine from this study whether the mRNA changes following estrogen treatment result in alterations of existing $\mathrm{GABA}_{\mathrm{A}}$ receptor subunit composition or an increase in the number of GABA $A_{A}$ receptors possessing $\alpha_{2}$ and $\gamma_{1}$ subunits. As it is believed that each $\mathrm{GABA}_{\mathrm{A}}$ receptor con- tains only one $\alpha$ subunit type (Duggan and Stephenson, 1990; McKernan et al., 1991), the increase in $\alpha_{2}$ mRNA observed here following estrogen may represent the inclusion of more $\alpha_{2}$ subunits within cach reccptor hetero-oligomer, or equally more $\mathrm{GABA}_{\mathrm{A}}$ receptors with an equivalent $\alpha_{2}$ subunit composition. It appears likely that one or multiple $\beta$ subunits are essential components of all $\mathrm{GABA}_{\mathrm{A}}$ receptors (Ymer et al., 1989; Sigel et al., 1990; Wisden et al., 1992; Amin and Weiss, 1993 ) and that the $\beta_{3}$ subunit may predominate within the MPN and BNST (Zhang et al., 1991; Wisden et al., 1992). Hence, it may be of significance that $\beta_{3}$ subunit mRNA is not altered by estrogen, suggesting that the number of $\mathrm{GABA}_{\mathrm{A}}$ receptors utilizing the $\beta_{3}$ subunit remain stable and that a change of $\alpha$ and $\gamma$ subunits within a $\beta_{3}$-containing $\mathrm{GABA}_{\mathrm{A}}$ receptor may occur. In preliminary observations, Petersen and colleagues (1993b) have similarly reported that estrogen treatment does not alter $\beta_{2}$ or $\beta_{3}$ subunit mRNA expression in the region of the organum vasculosum of the lamina terminalis.

Evidence for the regulation of $\mathrm{GABA}_{\mathrm{A}}$ receptors by estrogen reported here adds a further dimension to our understanding of estrogen-GABA interactions in the POA. Previous experiments have demonstrated that the local preoptic GABA neurons possess ERs (Flügge et al., 1986) and that extracellular GABA concentrations as measured in vivo by push-pull (Ondo et al., 1982) and microdialysis (Herbison et al., 1990, 1991a) are elevated in the presence of estrogen. Indirect evidence suggests that this effect of estrogen on GABA neurons is exerted through the genome (Herbison et al., 1991a) but that it does not involve changes in the activity (O'Connor et al., 1988) or mRNA expression (Herbison et al., 1992) of glutamic acid decarboxylase $_{67}$, the principle GABA synthetic enzyme. Estrogen has also been shown to modulate the stimulatory $\alpha$-adrenergic receptor-mediated input to GABA neurons in the POA (Herbison et al., 1990). Such effects of estrogen are likely to have important consequences for the neural control of behavior and reproduction as sexual behavior (Fernandez-Guasti et al., 1985; McCarthy et al., 1991) and locomotor activity (Osborne et al., 1993) as well as prolactin and luteinizing hormone secretion (Lamberts et al., 1983; Herbison et al., 1991b; Herbison and Dyer, 1991) are all altered by pharmacological manipulations of the preoptic GABA network. The demonstration here that estrogen can also alter $\mathrm{GABA}_{\mathrm{A}}$ receptor subunit mRNA expression in the $P O \Lambda$ indicates the complex and multifaceted influence of estrogen on neural networks involving GABA neurons in the POA of the rat.

\section{References}

Amin J, Weiss DS (1993) GABA $_{A}$ receptor needs two homologous domains of the $\beta$-subunit for activation by GABA but not by pentobarbital. Nature 366:565-569.

Araki T, Tohyama M (1992) Region-specific expression of GABA receptor $\alpha_{3}$ and $\alpha_{4}$ subunits mRNAs in the rat brain. Mol Brain Res 12:293-314.

Buchstaller A, Fuchs K, Sieghart W (1991) Identification of $\alpha_{1^{-}}, \alpha_{2}$ -

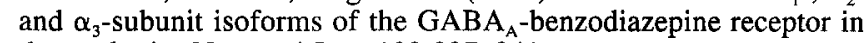
the rat brain. Neurosci Lell 129:237-241.

Bureau MH, Olsen RW (1993) $\mathrm{GABA}_{\mathrm{A}}$ receptor subtypes: ligand binding heterogeneity demonstrated by photoaffinity labeling and autoradiography. J Neurochem 61:1479-1491.

Canonaco M, Tavolaro R, Maggi A (1993) Steroid hormones and receptors of the $\mathrm{GABA}_{\mathrm{A}}$ supramolecular complex. Neuroendocrinology 57:974-984.

Cintra A, Fuxe K, Harfstrand A, Agnati LF, Miller LS, Greene JL, Gustafsson JA (1986) On the cellular localisation and distribution of estrogen receptors in the rat tel- and diencephalon using mono- 
clonal antibodies to human estrogen receptor. Neurochem Int 8:587-595.

Duggan MJ, Stephenson FA (1990) Biochemical evidence for the

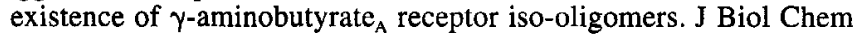
265:3831-3835.

Fernandez-Guasti A, Larsson K, Beyer C (1985) Comparison of the effects of different isomers of bicuculline infused in the preoptic area on male rat sexual behavior. Experientia 41:1414-1416.

Flügge G, Oertel WH, Wuttke W (1986) Evidence for estrogen-receptive GABAergic neurons in the preoptic/anterior hypothalamic area of the rat brain. Neuroendocrinology 43:1-5.

Freeman ME (1994) The neuroendocrine control of the ovarian cycle in the rat. In: The physiology of reproduction (Knobil E, Neill JD, eds), pp 613-658. New York: Raven.

Greene GL, Nolan C, Engler JP, Jensen EV (1980) Monoclonal antibodies to human estrogen receptor. Proc Natl Acad Sci USA 77: $5115-5119$

Herbison AE, Dyer RG (1991) Effect on luteinising hormone secretion of GABA receptor modulation in the medial preoptic area at the time of proestrous luteinising hormone stage. Neuroendocrinology 53:317-320.

Herbison AE, Theodosis DT (1992) Localisation of oestrogen receptors in preoptic neurons containing neurotensin but not tyrosine hydroxylase, cholecystokinin or luteinizing hormone-releasing hormone in the male and female rat. Neuroscience 50:283-298.

Herbison AE, Heavens RP, Dyer RG (1990) Oestrogen modulation of excitatory A1 noradrenergic input to rat medial preoptic gamma aminobutyric acid neurones demonstrated by microdialysis. Neuroendocrinology 52:161-168.

Herbison AE, Heavens RP, Dye S, Dyer RG (1991a) Acute action of oestrogen on medial preoptic gamma-aminobutyric acid neurons: correlation with oestrogen negative feedback on luteinizing hormone secretion. J Neuroendocrinol 3:101-106.

Herbison AE, Chapman C, Dyer RG (1991b) Role of medial preoptic GABA neurones in regulating luteinising hormone secretion in the ovariectomised rat. Exp Brain Res 87:345-352.

Herbison AE, Augood SJ, McGowan EM (1992) Expression of glutamic acid decarboxylase messenger RNA in rat medial preoptic area neurones during the oestrous cycle and after ovariectomy. Mol Brain Res 14:310-316.

Ju G, Swanson LW (1989) Studies on the cellular architecture of the bed nuclei of the stria terminalis in the rat: I. Cytoarchitecture. J Comp Neurol 280:587-602.

Khrestchatisky M, MacLennan AJ, Tillakaratne NJK, Chiang MY, Tobin AJ (1991) Sequence and regional distribution of the mRNA encoding the $\alpha_{2}$ polypeptide of rat $\gamma$-aminobutyric acid A receptors. J Neurochem 56:1717-1722.

Lamberts R, Vijayan E, Graf M, Mansky T, Wuttke W (1983) Involvement of preoptic-anterior hypothalamic GABA neurons in the regulation of pituitary $\mathrm{LH}$ and prolactin release. Exp Brain Res 52: 356-362.

Lasaga M, Duvilanski BH, Seilicovich A, Afione S, Debeljuk L (1988) Effect of sex steroids on GABA receptors in the rat hypothalamus and anterior pituitary gland. Eur J Pharmacol 155:163166.

Leipheimer RE, Bona-Gallo A, Gallo RV (1984) The influence of progesterone and estradiol on the acute changes in pulsatile luteinizing hormone release induced by ovariectomy on diestrus day 1 in the rat. Endocrinology 114:1605.

Luddens H, Wisden W (1991) Function and pharmacology of multiple GABA receptor subunits. Trends Pharmacol Sci 12:49-51.

MacLennan AJ, Brecha N, Khrestchatisky M, Sternini C, Tillakaratne NJK, Chiang MY, Anderson K, Lai M, Tobin AJ (1991) Independent cellular and ontogenetic expression of mRNAs encoding three $\alpha$ polypeptides of the rat GABA A $_{\text {receptor. Neuroscience } 43: 369}$ 380.

Maggi A, Perez J (1986) Estrogen-induced up-regulation of $\gamma$-aminobutyric acid receptors in the CNS of rodents. J Neurochem 47 : 1793-1797.

Majewska MD (1992) Neurosteroids: endogenous bimodal modulators of the $\mathrm{GABA}_{\mathrm{A}}$ receptor. Mechanism of action and physiological significance. Prog Neurobiol 38:379-395.

Mayer ML (1981) Electrophysiological analysis of inhibitory synaptic mechanisms in the preoptic area of the rat. J Physiol (Lond) 316:327-346.
McCarthy MM, Masters DB, Fiber JM, López-Colomé A-M, Beyer C, Komisaruk BR, Feder HH (1991) GABAergic control of receptivity in the female rat. Neuroendocrinology 53:473-479.

McKernan RM, Quirk K, Prince R, Cox PA, Gillard NP, Ragan I, Whiting $P$ (1991) GABA $_{A}$ receptor subtypes immunopurified from rat brain with $\alpha$ subunit-specific antibodies have unique pharmacological properties. Neuron 7:667-676.

Nayeem N, Green TP, Martin IL, Barnard EA (1994) Quaternary structure of the native $\mathrm{GABA}_{\mathrm{A}}$ receptor determined by electron microscopic image analysis. J Neurochem 62:815-818.

O'Connor LH, Nock B, McEwen BS (1988) Regional specificity of gamma-aminobutyric acid receptor regulation by estradiol. Neuroendocrinology 47:473-481.

Olsen RW, McCabe RT, Wamsley JK (1990) GABA receptor subtypes: autoradiographic comparison of $\mathrm{GABA}_{\mathrm{A}}$, benzodiazepine, and convulsant binding sites in the rat central nervous system. $J$ Chem Neuroanat 3:59-76.

Ondo J, Mansky T, Wuttke W (1982) In vivo GABA release from the medial preoptic area of diestrous and ovariectomized rats. Exp Brain Res 46:69-72.

Osborne PG, Mataga N, Onoe H, Watanabe Y (1993) Behavioral activation by stimulation of a GABAergic mechanism in the preoptic area of rat. Neurosci Lett 158:201-204.

Paul SM, Purdy RH (1992) Neuroactive steroids. FASEB J 6:23112322.

Petersen SL, McCrone S, Coy D, Adelman JP, Mahan LC (1993a) $\mathrm{GABA}_{\mathrm{A}}$ receptor subunit mRNAs in cells of the preoptic area: colocalization with LHRH mRNA using dual-label in situ hybridization histochemistry. Endocr J 1:29-34.

Petersen SL, Reeves A, Keller M, Gardener E, Mahan LC, McCrone $S$ (1993b) Effects of estradiol $\left(E_{2}\right)$ and progesterone $\left(P_{4}\right)$ on expression of mRNAs encoding GABA, receptor subunits. Soc Neurosci Abstr 19:489.14

Pfaff DW, Schwartz-Giblin S, McCarthy MM, Kow L-M (1994) Cellular and molecular mechanisms of female reproductive behaviors. In: The physiology of reproduction (Knobil E, Neill JD, eds), pp 107-220. New York: Raven.

Pritchett DB, Luddens H, Seeberg PH (1989) Type I and type II $\mathrm{GABA}_{\mathrm{A}}$-benzodiazepine receptors produced in transfected cells. Science 245:1389-1392.

Schumacher M, Coirini H, McEwen BS (1989a) Regulation of highaffinity $\mathrm{GABA}_{\mathrm{A}}$ receptors in the dorsal hippocampus by estradiol and progesterone. Brain Res 487:178-183.

Schumacher M, Coirini H, McEwen BS (1989b) Regulation of highaffinity $\mathrm{GABA}_{\mathrm{A}}$ receptors in specific brain regions by ovarian hormones. Neuroendocrinology 50:315-320.

Shu S, Ju G, Fan L (1988) The glucose oxidase-DAB-nickel method in peroxidase histochemistry of the nervous system. Neurosci Lett 85:169-171.

Sigel E, Baur R, Trube G, Mlauohler H, Malherbe P (1990) The effect of subunit composition of rat brain $\mathrm{GABA}_{\wedge}$ receptors on channel function. Neuron 5:703-711.

Simerly RB, Chang C, Muramatsu M, Swanson LW (1990) Distribution of androgen and estrogen receptor mRNA-containing cells in the rat brain: an in situ hybridization study. J Comp Neurol 294: 76-95.

Terasawa E, Kawakami M (1974) Positive feedback sites of estrogen in the brain on ovulation: possible role of bed nucleus of the stria terminalis and amygdala. Endocrinol Jpn 21:51-68.

Tetel MJ, Getzinger MJ, Blaustein JD (1993) Fos expression in the rat brain following vaginal-cervical stimulation by mating and manual probing. J Neuroendocrinol 5:397-404.

Wafford KA, Whiting PJ, Kemp JA (1993) Differences in affinity and efficacy of benzodiazepine receptor ligands at recombinant $\gamma$-aminobutyric $\operatorname{acid}_{\mathrm{A}}$ receptor subtypes. Mol Pharmacol 43:240244.

Wisden W, Laurie DJ, Monyer H, Seeburg PH (1992) The distribution of $13 \mathrm{GABA}_{\mathrm{A}}$ receptor subunit mRNAs in the rat brain. I. Telencephalon, diencephalon, mesencephalon. J Neurosci 12:1040-1062.

Ymer S, Schofield PR, Draguhn A, Werner P, Kuhler M, Seeburg PH (1989) $\mathrm{GABA}_{\mathrm{A}}$ receptor $\boldsymbol{\beta}$ subunit heterogeneity: functional expression of cloned cDNAs. EMBO J 8:1665-1670.

Ymer S, Draguhn A, Wisden W, Werner P, Keinänen K, Schofield PR, Sprengel R, Pritchett DB, Seeburg PH (1990) Structural and func- 
tional characterisation of the $\gamma_{1}$ subunit of GABA $A_{A} /$ benzodiazepine receptors. EMBO J 9:3261-3267.

Zezula J, Fuchs K, Sieghart W (1991) Separation of $\alpha_{1}, \alpha_{2}$ and $\alpha_{3}$ subunits of the $\mathrm{GABA}_{\mathrm{A}}$-benzodiazepine receptor complex by immunoaffinity chromatography. Brain Res 563:325-328.

Zhang J-H, Sato M, Tohyama M (1991) Region specific expression of the mRNAs encoding $\beta$ subunits $\left(\beta_{1}, \beta_{2}\right.$ and $\left.\beta 3\right)$ of $\mathrm{GABA}_{\mathrm{A}}$ receptor in the rat brain. J Comp Neurol 303:637-657.

Zimprich F, Zezula J, Sieghart W, Lassmann H (1991) Immunohistochemical localisation of the $\alpha_{1}, \alpha_{2}$ and $\alpha_{3}$ subunit of the GABA receptor in the rat brain. Neurosci Lett 127:125-128. 